\title{
Uncovering the Neoproterozoic Carbon Cycle
}

\section{Citation}

Johnston, D. T., F. A. Macdonald, B. C. Gill, P. F. Hoffman, and D. P. Schrag. 2012. Uncovering the Neoproterozoic Carbon Cycle. Nature 483: 320-323.

\section{Published Version}

10.1038/nature10854

\section{Permanent link}

http://nrs.harvard.edu/urn-3:HUL.InstRepos:12748671

\section{Terms of Use}

This article was downloaded from Harvard University's DASH repository, and is made available under the terms and conditions applicable to Other Posted Material, as set forth at http:// nrs.harvard.edu/urn-3:HUL.InstRepos:dash.current.terms-of-use\#LAA

\section{Share Your Story}

The Harvard community has made this article openly available.

Please share how this access benefits you. Submit a story.

Accessibility 
Uncovering the Neoproterozoic carbon cycle

\author{
D.T. Johnston ${ }^{1}$, F.A. Macdonald ${ }^{1}$, B.C. Gill ${ }^{1}$, P.F. Hoffman ${ }^{1,2}$, D.P. Schrag ${ }^{1}$ \\ ${ }^{1}$ Department of Earth and Planetary Sciences, Harvard University, 20 Oxford Street, Cambridge \\ MA 02138
}

${ }^{2}$ School of Earth and Ocean Sciences, University of Victoria, Victoria, BC V8W 2Y2, Canada

Abstract: 282/300 words -- Body text: 1827/1500 -- Refs:32/30 -- Display items: 3/3

Interpretations of major climatic and biological events in Earth history are, in large part, derived from the stable carbon isotope records of carbonate rocks and sedimentary organic matter ${ }^{1,2}$. Neoproterozoic carbonate records contain uniquely dramatic negative isotopic anomalies within long periods (10-100 million years) of enriched $\delta^{13} \mathrm{C}_{\text {carb }}$ of $>+5 \%$. Classically, $\delta^{13} \mathrm{C}_{\text {carb }}$ is interpreted as a metric of the relative fraction of carbon buried as organic matter $\left(f_{\text {org }}\right)$ in marine sediments ${ }^{2-4}$, which can be linked to $\mathrm{O}_{2}$ accumulation through the stoichiometry of primary production $^{3,5}$. If a change in the isotopic composition of marine dissolved inorganic carbon (DIC) is responsible for these excursions, it is expected that $\delta^{13} C_{c a r b}$ and $\delta^{13} C_{\text {org }}$ records will covary, offset by the fractionation imparted by primary production $\left(\varepsilon_{\mathrm{p}}\right)^{5}$. The documentation of several Neoproterozoic $\delta^{13} \mathrm{C}_{\text {carb }}$ excursions decoupled from $\delta^{13} C_{o r g}$, however, has spurred alternative models ${ }^{6-8}$ for their generation. To better diagnose the behavior of the Neoproterozoic carbon cycle, we present $\delta^{13} \mathrm{C}$ data from Mongolia, northwest Canada and Namibia that capture multiple large amplitude (>10\%) negative carbon isotope anomalies and pair these data with a new quantitative mixing model. Carbonate and organic carbon data from Mongolia and Canada record tight covariance through multiple $\delta^{13} \mathrm{C}_{\text {carb }}$ excursions, quantitatively ruling out diagenesis or the presence and terminal oxidation of a large marine dissolved organic carbon (DOC) reservoir as potential drivers. Our data from Namibia, which like many other data sets does not record isotopic covariance, can all be explained by simple mixing with a detrital flux of organic matter. We thus interpret $\delta^{13} \mathrm{C}_{\text {carb }}$ anomalies as recording a primary 
perturbation to the surface carbon cycle. This interpretation requires revisiting models linking dramatic isotope excursions to deep ocean oxygenation and the opening of environments capable of supporting animals ${ }^{9-11}$.

There are two leading hypotheses for the documented large amplitude ${ }^{12}$ Neoproterozoic carbon isotope anomalies. The first proposal is that the Neoproterozoic deep ocean carried a massive DOC reservoir ${ }^{6}$. This model stems from the observation of unlinked changes in $\delta^{13} \mathrm{C}_{\text {carb }}$ and $\delta^{13} \mathrm{C}_{\text {org }}$, with the postulated large DOC pool allowing for $\delta^{13} \mathrm{C}_{\text {org }}$ records to be buffered against isotopic change. Another view of these large carbon isotopic excursions is represented by a set of hypotheses arguing for the infidelity of $\delta{ }^{13} \mathrm{C}_{\text {carb }}$ records. In this view, secondary alteration by meteoric waters or burial diagenesis is invoked to satisfy carbon isotope decoupling ${ }^{7,8}$. Given such disparate proposals for explaining the Neoproterozoic carbon isotope record, and the implications for surface environments, climate, $\mathrm{O}_{2}$, and animals, we look to revisit the behavior of the marine carbon cycle and test the validity of the aforementioned proposals with a new dataset and model.

Stratigraphic sections spanning the mid-Neoproterozoic Cryogenian glacial intermission $(<717$ to $>635$ million years ago, Ma) were sampled at high-resolution in Mongolia, northern Namibia, and northwest Canada ${ }^{13}$. In Mongolia, limestone of the Tayshir member (Tsagaan Oloom Formation) is bracketed by the Maikhan Ul and Khongoryn diamictites ${ }^{14}$ (Fig. 1). The Tayshir carbon isotope anomaly ${ }^{14}$ is recorded in stratigraphic sections throughout the basin, commences with a distinct flooding surface, and is developed predominantly in limestone micrite with relatively low primary porosity. The Tayshir anomaly can be either correlated to moderately negative values in the Gruis Formation of northern Namibia ${ }^{15}$ and Bonahaven Dolomite of the British-Irish Caledonides $^{16}$, or to the Trezona anomaly in Australia ${ }^{17}$ and Namibia ${ }^{18,19}$. The Trezona was also sampled through the Ombaatjie Formation in northern Namibia ${ }^{13}$, which directly underlies an erosion surface related to the $635.5 \pm 1.2 \mathrm{Ma}$ Ghaub glaciation $^{20}$. The Cryogenian record from between the glaciations was further sampled in the Mackenzie Mountains of northwest Canada ${ }^{13}$, where mixed carbonate and siliciclastic rocks of the Twitya and Keele formations are bounded by diamictites of the $716.47 \pm 0.24 \mathrm{Ma}$ 
Rapitan Group ${ }^{21}$ and Marinoan-age Icebrook Formation. These strata preserve the postSturtian Rasthof anomaly in the Twitya Formation and an anomaly at the top of the Keele Formation that can be correlated to the Trezona ${ }^{22}$. Though we note published correlations for particular anomalies above, these correlations are not central to our argument.

We present two $\delta^{13} \mathrm{C}_{\text {carb }}$ and $\delta^{13} \mathrm{C}_{\text {org }}$ records through the Tayshir member of Mongolia (Fig. 1). The overall TOC contents broadly follow siliciclastic content and are highest at the base of the more distal section (Uliastay Gol), but remain at $\sim 0.08 \%$ throughout the succession with no apparent facies dependence ${ }^{13}$. In the Uliastay Gol section ( $\mathrm{n}=171$ pairs), a $>10 \%$ negative $\delta^{13} \mathrm{C}_{\text {carb }}$ anomaly (the Tayshir) at $\sim 150$ meters preserves an extremely tight coupling with $\delta^{13} \mathrm{C}_{\text {org }}$ through the entire excursion. Isotopic covariance is observed at even finer stratigraphic scales, such as the inflection recorded at $\sim 50$ meters. Consistent with this, a parallel section $35 \mathrm{~km}$ to the east also preserves a tight isotopic coupling and similar net isotopic offset, or $\varepsilon_{\text {TOC }}\left(=\delta^{13} \mathrm{C}_{\text {carb }}-\delta^{13} \mathrm{C}_{\text {org }}\right)(\mathrm{Fig} .1)^{13}$.

In northwest Canada, the Cryogenian Twitya and Keele formations provide a comparison to glacial intermission records from Mongolia, and preserve the Rasthof and a latest Cryogenian isotope excursion (Fig. 2). The post-Sturtian Twitya Formation preserves strong covariance in $\delta^{13} \mathrm{C}_{\text {carb }}-\delta^{13} \mathrm{C}_{\text {org }}$ and an $\varepsilon_{\mathrm{TOC}}$ that closely approximates that measured in Mongolia ${ }^{13}$. The pre-Marinoan Keele Formation also appears to preserve $\delta^{13} \mathrm{C}_{\text {carb }}-\delta^{13} \mathrm{C}_{\text {org }}$ covariance, but records a more variable $\varepsilon_{\mathrm{TOC}}$, ranging from values similar to those observed in Mongolia to that recorded in the Pleistocene ${ }^{5,13}$. Juxtaposed to these records of tight covariance is the Trezona anomaly in Namibia (a TOC poor dolo-mudstone, -grainstone, and -microbialaminite ${ }^{13}$ ), where $\delta^{13} \mathrm{C}_{\text {carb }}$ and $\delta^{13} \mathrm{C}_{\text {org }}$ carry little genetic relationship to one another. This later observation is consistent with much of the published Neoproterozoic data ${ }^{6,10,11,23}$. Our data set thus reflects both the convention (isotopic decoupling) as well as strong evidence of isotopic covariance.

With these data we now look to evaluate the behavior of the late Cryogenian carbon cycle. The classic interpretation of isotopic covariance suggests that biomass is synthesized from a relatively well-mixed marine DIC reservoir and results in an $\varepsilon_{\mathrm{TOC}}$ that 
largely reflects a kinetic fractionation associated with carbon fixation ${ }^{2,13}$. This simple depiction of the C-cycle cleanly explains records from Mongolia and northwest Canada (Figs. 1,2). Our finding stands in stark opposition to models requiring a large DOC pool, which would preclude covariance between $\delta^{13} \mathrm{C}_{\text {carb }}$ and $\delta^{13} \mathrm{C}_{\mathrm{org}}$. Put differently, data from Mongolia and northwest Canada are quantitatively inconsistent with a large DOC model (Figs 1-2). It has also been argued that burial diagenesis ${ }^{8}$ or meteoric alteration ${ }^{7}$ could reset the primary $\delta^{13} \mathrm{C}_{\text {carb }}$, calling into question the robustness of carbonate records and their use as a pre-fossil correlation tool. Rather than targeting the fidelity of $\delta^{13} \mathrm{C}_{\mathrm{org}}$, these studies emphasize the tight covariance between $\delta^{13} \mathrm{C}_{\text {carb }}$ and $\delta^{18} \mathrm{O}_{\text {carb }}$ through certain negative $\delta^{13} \mathrm{C}_{\text {carb }}$ excursions as evidence for alteration ${ }^{13}$. However, the observation of a tight coupling between $\delta^{13} \mathrm{C}_{\text {carb }}$ and $\delta^{13} \mathrm{C}_{\text {org }}$ through several Neoproterozoic anomalies (Figs. 1-2) rules out alteration as the primary cause of all large Neoproterozoic negative $\delta^{13} \mathrm{C}_{\text {carb }}$ excursions ${ }^{13}$. The $\delta^{18} \mathrm{O}_{\text {carb }}$ in these rocks is almost certainly reset, given fluid-rock exchange and the high concentration of oxygen in water, but explaining how exchange can reset $\delta^{13} \mathrm{C}_{\text {carb }}$ given the enormous mass of carbon in carbonate sequences is more challenging ${ }^{8}$. The correlation of $\delta^{13} \mathrm{C}_{\text {carb }}$ and $\delta^{18} \mathrm{O}_{\text {carb }}$ is intriguing and may in fact have an environmental/diagenetic explanation ${ }^{13}$, but will require further investigation. Importantly however, diagenesis is not responsible for the excursions through which $\delta^{13} \mathrm{C}$ covaries (Figs 1-2).

A complete understanding of the Neoproterozoic carbon cycle requires not only the interpretation of carbon isotope covariance (Figs. 1-2) 2,4 , but also an explanation for the data that underpinned these alternative hypotheses. We propose that much of the existing $\delta^{13} \mathrm{C}_{\text {org }}$ from Neoproterozoic sedimentary rocks reflects contamination with a secondary source of organic carbon, possibly from the erosion of organic-rich shale on land or the migration of hydrocarbons within the basin. The isotopic contribution from exogenous sources would be most evident when TOC values are low consistent with a majority of the published data ${ }^{10,23}$. This hypothesis does not require that all samples with low TOC carry anomalous $\delta^{13} \mathrm{C}_{\mathrm{org}}$, but notes the greater susceptibility of these samples ${ }^{2,4,24}$ and challenges their universal inclusion in environmental interpretations, especially when $\delta^{13} \mathrm{C}_{\text {org }}$ remains constant through intervals when $\delta^{13} \mathrm{C}_{\text {carb }}$ is variable. 
To explore the hypothesis that these data are produced from both an exogenous component and a primary source, we present a model for two-component mixing (Fig. 3a-b). Here, each component carries an organic carbon flux (monitored by TOC) and a distinct $\delta^{13} \mathrm{C}_{\mathrm{org}}$, thus the product of mixing does not require a linear relationship between components ${ }^{13}$. One component in the model is organic carbon from primary producers (Fig. 3a, A), with a high mass fraction and an isotopic composition offset from DIC by $\varepsilon_{\text {TOC. }}$. The second component $(B)$ is exogenous, and could be terrigenous (detrital) inputs, secondary hydrocarbons, or contamination at some point on the rock's life history (with an isotopic composition in the range of typical organic matter). Post-depositional processes, such as heterotrophic remineralization, will also alter mixed contributions (Fig. 3b). When then compared to $\delta^{13} \mathrm{C}_{\text {carb }}$ (Fig. 3c-d), this simple mixing model fully describes Cyrogenian and Ediacaran records without invoking alteration ${ }^{7,8}$ or unfamiliar ocean chemistry ${ }^{6,10,11,23}$. Our model does not require developing and oxidizing an ocean where DOC overwhelms DIC multiple times throughout the Neoproterozoic, or driving wholesale alteration of carbonate platform sediments across the globe. This does not preclude contributions from $\mathrm{DOC}^{25}$, however the observation of isotopic covariance at the scales observed requires DOC be significantly subordinate to DIC $^{25}$. Therefore, we find our model more plausible from a physical and chemical oceanographic standpoint, as it only requires established, well-understood processes (i.e. weathering, a circulating ocean, and remineralization). It follows from these conclusions that $\delta^{13} \mathrm{C}_{\text {carb }}$ may be a more faithful indicator of environmental change, and $\delta^{13} \mathrm{C}_{\text {org }}$ should be viewed critically, especially when TOC is low and invariant.

Given evidence in support of the potential fidelity of $\delta^{13} \mathrm{C}_{\text {carb }}$ to preserve primary environmental information, we revisit the reading of this record. The conventional interpretation of the carbon cycle and isotope records uses a simplification of the full carbon flux equation for isotopic mass balance, where $\delta^{13} \mathrm{C}_{\mathrm{vol}}=\left[\delta^{13} \mathrm{C}_{\text {org }} \mathrm{x} f_{\text {org }}\right]+\left[\delta^{13} \mathrm{C}_{\text {carb }}\right.$ $\left.\mathrm{x}\left(1-f_{\text {org }}\right)\right]$. If one considers the full carbon flux equation (where $\delta^{13} \mathrm{C}$ inputs reflect a weighted average of volcanism [carbon entrained during subduction and mantle outgassing] and carbonate and organic carbon weathering ${ }^{26,27}$, and where sinks include both carbonate and organic matter burial), alternative means of driving $\delta^{13} \mathrm{C}$ variations 
become apparent. Each of the above listed fluxes can change in magnitude and isotopic composition, and each carry specific consequences for climate and oxidant budgets. Another important challenge is that the Neoproterozoic $\delta^{13} \mathrm{C}$ excursions occur in $10 \mathrm{~s}$ to $100 \mathrm{~s}$ of meters of shallow-water strata (third-order sequence tracts), implying a characteristic timescale of $10^{5}$ to $10^{6}$ years $^{28}$. It is challenging to produce such large (i.e., $\sim 10 \%$ ) isotopic excursions, which in certain cases plunge beyond the canonical mantle value, on these timescales without the input of an enormous mass of low $\delta^{13} \mathrm{C}$ carbon, presumably in the form of either organic matter or methane ${ }^{29}$. This requisite light carbon load may, in part, reflect the mass-balance counterpart to enriched background Cryogenian $\delta{ }^{13} \mathrm{C}_{\text {carb }}$ values. It would be further expected that such an injection of carbon would significantly raise atmospheric $p \mathrm{CO}_{2}$ or $p \mathrm{CH}_{4}$ and consume existing oxidant reservoirs ${ }^{30}$, which is difficult to reconcile with the close stratigraphic association of at least some of the excursions and glacial deposits ${ }^{27}$. Another possibility is that the oxidation of reduced carbon is accomplished with $\mathrm{SO}_{4}{ }^{2-}$ or Fe-oxides as an electron acceptor $^{31}$, rather than $\mathrm{O}_{2}$, which may allow for some stabilization of $p \mathrm{CO}_{2}$ through the effect on alkalinity ${ }^{25}$. If the duration of these events is found to be longer, then carbon mass input arguments would be modified accordingly, however the relevant reservoirs interacting with the surface $\mathrm{C}$-cycle remain unchanged.

The data and analysis presented here illustrates that $\delta^{13} \mathrm{C}_{\text {carb }}$ preserves a faithful snapshot of the Neoproterozoic surface carbon cycle. This suggests that there is an environmental explanation for the enriched $\delta^{13} \mathrm{C}_{\text {carb }}$ background values, and that at least some of the $10^{5}-10^{6}$ year negative $\delta^{13} \mathrm{C}_{\text {carb }}$ excursions reflect primary features of the surface carbon cycle. These anomalies thus require the episodic input of isotopically light carbon, presumably methane or organic matter, as well as the cyclic consumption and production of electron acceptors such as sulfate and $\mathrm{O}_{2}$. Our data do not eliminate diagenetic explanations for particular excursions throughout the world; however, the documentation of covariation during many of the excursions does encourage a common explanation for all of them. Whether these excursions are driven by the recycling of stored carbon in the form of methane hydrate or ancient organic matter in sediments, or by the dynamics of nutrient-dependent productivity in the ocean remains uncertain. 
Consistent with both is the idea is that these excursions simply reflect a series of attempts to transition from the more reducing and biologically simple Proterozoic world to the more oxidizing and biologically complex Phanerozoic Earth.

Method Summary: All isotope data are presented relative to Vienna PeeDee Belemnite (VPDB) and calculated according to standard delta notation and reported in units of \%o. Carbonate carbon and oxygen isotope measurements made as one individual measurement, with the organic carbon isotopic composition measured separately, but on the same hand sample. Carbonate carbon isotopes were prepared by cutting hand samples to expose a fresh surface followed by micro-drilling $10^{-2}$ grams. A small aliquot of this powder was analyzed on a VG Optima run in dual inlet mode, abutted to a common acid bath preparation device. Samples were acidified in $\mathrm{H}_{3} \mathrm{PO}_{4}$ at $90^{\circ} \mathrm{C}$. The evolved $\mathrm{CO}_{2}$ was cyro-focused and analyzed against an in-house standard reference gas. The reproducibility of this measurement was better than $0.1 \%$ ( 1 standard deviation). Organic carbon analyses were performed on large ( $\sim 10$ gram $)$ samples as to accommodate low TOC values. Samples were decalcified with concentrated $\mathrm{HCl}$ for 48 hours, buffered back to a neutral $\mathrm{pH}(>\mathrm{pH} 5)$, filtered, and dried. The mass of insoluble residue was taken as siliciclastic content. Homogenized residues were analyzed on a Carlo Erba Elemental Analyzer attached to a ThermoFinnigan Delta V configured in continuous flow mode. Samples and standards were bracketed such that our $>350$ unique organic carbon analyses (each run in duplicate) were associated with 370 internal standards. These standards have known organic carbon contents and isotope values, and as such, were used to calibrate TOC contents and isotopic compositions. Estimates of error are also reported in the text. The simple mixing model underpinning Fig. 3 is a standard multi-component mixing scenario. 


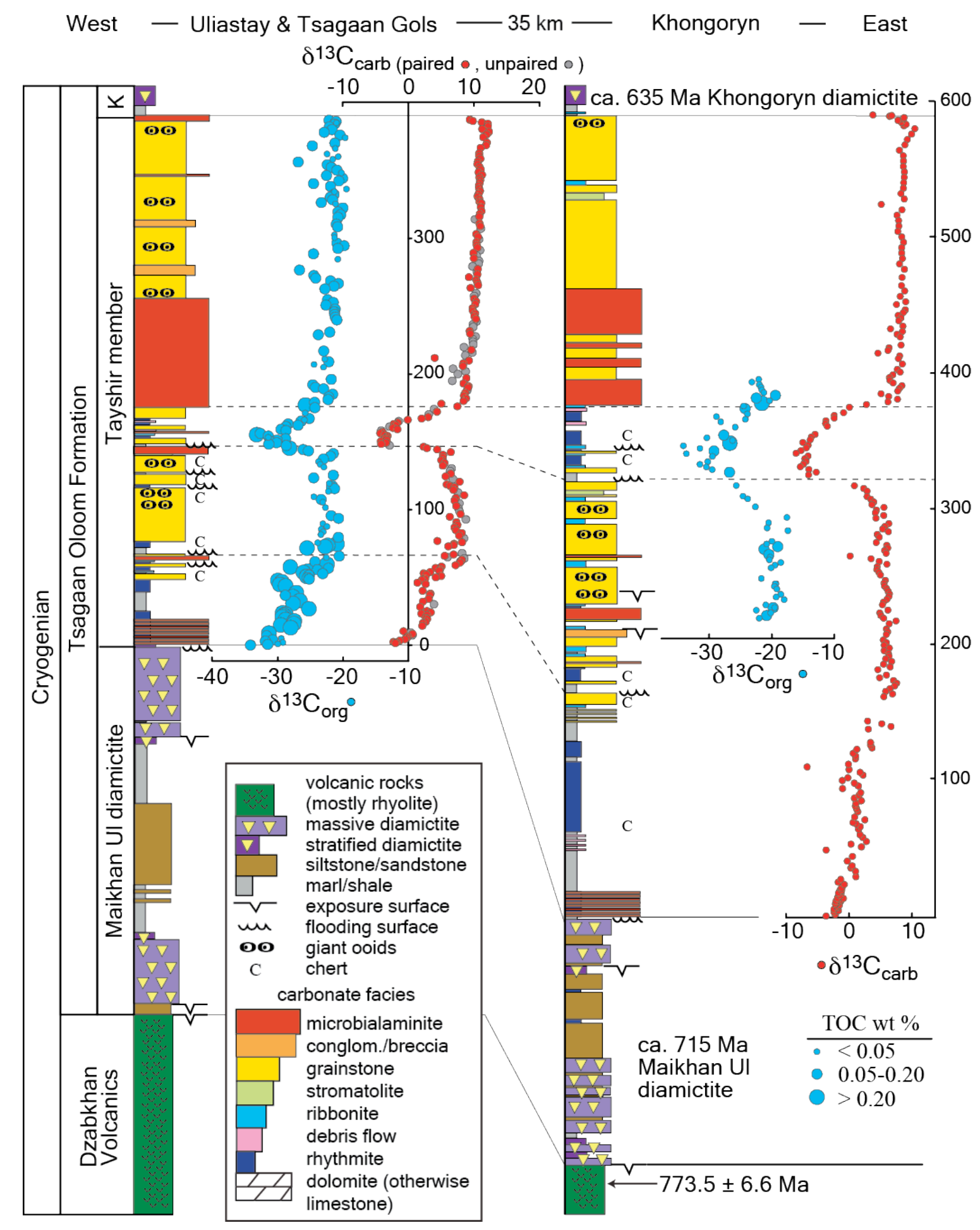

Uncovering the Neoproterozoic carbon cycle 


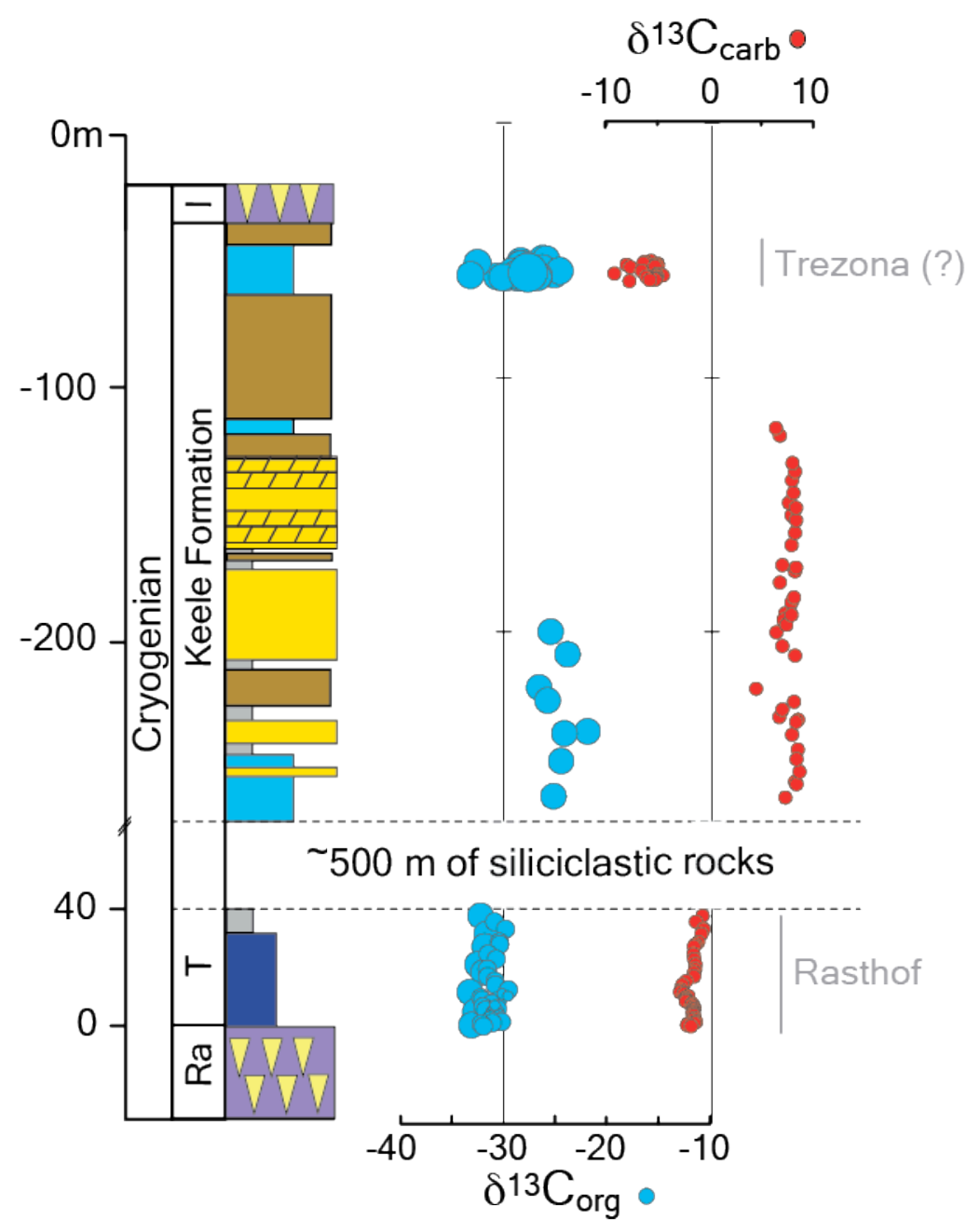



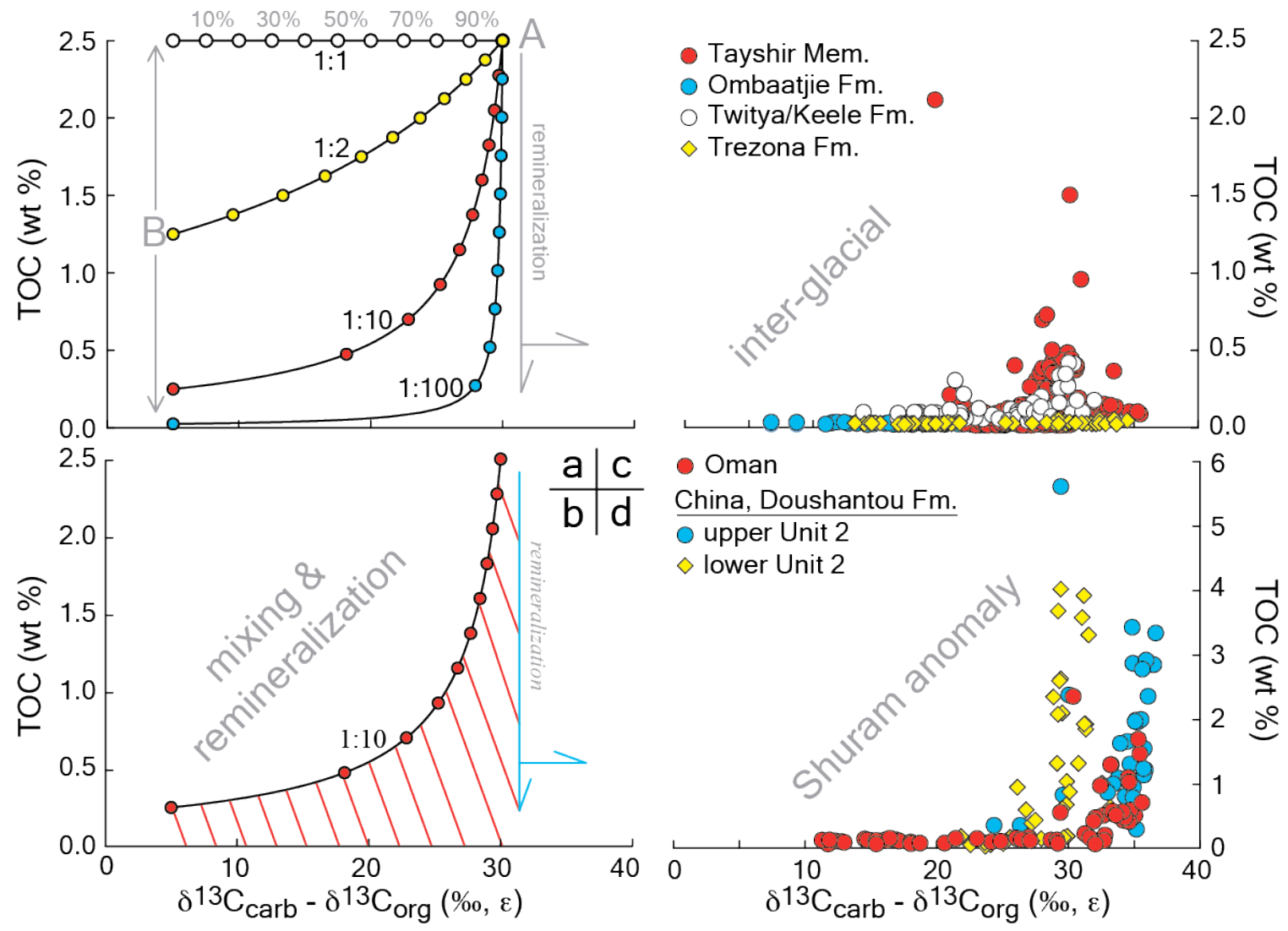
1 Halverson, G. P., Wade, B. P., Hurtgen, M. T. \& Barovich, K. M. Neoproterozoic chemostratigraphy. Precambrian Research 182, 337-350, doi:10.1016/j.precamres.2010.04.007 (2010).

2 Knoll, A. H., Hayes, J. M., Kaufman, A. J., Swett, K. \& Lambert, I. B. Secular variation in carbon isotope ratios from upper Proterozoic successions of Svalbard and east Greenland. Nature 321, 832-838 (1986).

3 DesMarais, D. J., Strauss, H., Summons, R. E. \& Hayes, J. M. Carbon isotope evidence for the stepwise oxidation of the Proterozoic environment. Nature 359, 605-609 (1992).

4 Kaufman, A. J., Knoll, A. H. \& Narbonne, G. M. Isotopes, ice ages, and terminal Proterozoic earth history. Proceedings of the National Academy of Sciences of the United States of America 94, 6600-6605 (1997).

5 Hayes, J. M., Strauss, H. \& Kaufman, A. J. The abundance of C-13 in marine organic matter and isotopic fractionation in the global biogeochemical cycle of carbon during the past 800 Ma. Chemical Geology 161, 103-125 (1999).

6 Rothman, D. H., Hayes, J. M. \& Summons, R. E. Dynamics of the Neoproterozoic carbon cycle. Proceedings of the National Academy of Sciences of the United States of America 100, 8124-8129, doi:10.1073/pnas.0832439100 (2003).

7 Knauth, L. P. \& Kennedy, M. J. The late Precambrian greening of the Earth. Nature 460, 728-732, doi:10.1038/nature08213 (2009).

8 Derry, L. A. A burial diagenesis origin for the Ediacaran Shuram-Wonoka carbon isotope anomaly. Earth and Planetary Science Letters 294, 152-162, doi:10.1016/j.epsl.2010.03.022 (2010).

9 Canfield, D. E., Poulton, S. W. \& Narbonne, G. M. Late-Neoproterozoic deepocean oxygenation and the rise of animal life. Science 315, 92-95 (2007).

10 Fike, D. A., Grotzinger, J. P., Pratt, L. M. \& Summons, R. E. Oxidation of the Ediacaran Ocean. Nature 444, 744-747, doi:10.1038/nature05345 (2006).

11 McFadden, K. A. et al. Pulsed oxidation and bioloical evolution in the Ediacaran Doushantuo Formation. Proceedings of the National Academy of Sciences of the United States of America 105, 3197-3202, doi:10.1073/pnas.0708336105 (2008). 
12 Grotzinger, J. P., Fike, D. A. \& Fischer, W. W. Enigmatic origin of the largestknown carbon isotope excursion in Earth's history. Nature Geoscience 4, 285-292, doi:10.1038/ngeo1138 (2011).

13 material, S. O.

14 Macdonald, F. A., Jones, D. S. \& Schrag, D. P. Stratigraphic and tectonic implications of a new glacial diamictite-cap carbonate couplet in southwestern Mongolia. Geology 37, 123-126 (2009).

15 Halverson, G. P., Hoffman, P. F., Schrag, D. P., Maloof, A. C. \& Rice, A. H. N. Toward a Neoproterozoic composite carbon-isotope record. Geological Society of America Bulletin 117, 1181-1207 (2005).

16 McCay, G. A., Prave, A. R., Alsop, G. I. \& Fallick, A. E. Glacial trinity: Neoproterozoic Earth history within the British-Irish Caledonides. Geology 34, 909-912 (2006).

17 McKirdy, D. M. et al. A chemostratigraphic overview of the late Cryogenian interglacial sequence in the Adelaide fold-thrust belt, South Australia. Precambrian Research 106, 149-186 (2001).

18 Halverson, G. P., Hoffman, P. F., Schrag, D. P. \& Kaufman, A. J. A major perturbation of the carbon cycle before the Ghaub glaciation (Neoproterozoic) in Namibia: prelude to snowball Earth? Geochemistry, Geophysics, Geosystems 3, no. 6, doi: 10.1029/2001GC000244, doi:10.1029/2001GC000244. (2002).

19 Hoffman, P. F., Kaufman, A. J., Halverson, G. P. \& Schrag, D. P. A Neoproterozoic snowball earth. Science 281, 1342-1346 (1998).

20 Hoffmann, K. H., Condon, D. J., Bowring, S. A. \& Crowley, J. L. U-Pb zircon date from the Neoproterozoic Ghaub Formation, Namibia: Constraints on Marinoan glaciation. Geology 32, 817-820, doi:10.1130/g20519.1 (2004).

21 Macdonald, F. A. et al. Calibrating the Cryogenian. Science 327, 1241-1243, doi:10.1126/science.1183325 (2010).

22 Hoffman, P. F. \& Schrag, D. P. The snowball Earth hypothesis: testing the limits of global change. Terra Nova 14, 129-155 (2002).

23 Swanson-Hysell, N. L. et al. Cryogenian Glaciation and the Onset of CarbonIsotope Decoupling. Science 328, 608-611, doi:10.1126/science.1184508 (2010). 
24 Dehler, C. M. et al. High-resolution delta C-13 stratigraphy of the Chuar Group (ca. 770-742 Ma), Grand Canyon: Implications for mid-Neoproterozoic climate change. Geological Society of America Bulletin 117, 32-45, doi:10.1130/b25471.1 (2005).

25 Tziperman, E., Halevy, I., Johnston, D. T., Knoll, A. H. \& Schrag, D. P. Biologically induced Snowball Earth. Proceedings of the National Academy of Sciences (2011).

26 Hayes, J. M. \& Waldbauer, J. R. The carbon cycle and associated redox processes through time. Philosophical Transactions of the Royal Society B-Biological Sciences 361, 931-950 (2006).

27 Schrag, D. P., Berner, R. A., Hoffman, P. F. \& Halverson, G. P. On the initiation of a snowball Earth. Geochemistry Geophysics Geosystems 3, doi:103610.1029/2001gc000219 (2002).

28 Halverson, G. P., Hoffman, P. F., Schrag, D. P. \& Kaufman, A. J. A major perturbation of the carbon cycle before the Ghaub glaciation (Neoproterozoic) in Namibia: Prelude to snowball Earth? Geochemistry Geophysics Geosystems 3, doi:103510.1029/2001gc000244 (2002).

29 Bjerrum, C. J. \& Canfield, D. E. Towards a quantitative understanding of the late Neoproterozoic carbon cycle. Proceedings of the National Academy of Science 108, 5542-5547 (2011).

30 Bristow, T. F. \& Kennedy, M. J. Carbon isotope excursions and the oxidant budget of the Ediacaran atmosphere and ocean. Geology 36, 863-866, doi:10.1130/g24968a.1 (2008).

31 Johnston, D. T. et al. An emerging picture of Neoproterozoic ocean chemistry: Insights from the Chuar Group, Grand Canyon, USA. Earth and Planetary Science Letters 290, 64-73, doi:10.1016/j.epsl.2009.11.059 (2010).

32 Levashova, N. M. et al. The origin of the Baydaric microcontinent, Mongolia: Constraints from paleomagnetism and geochronology. Tectonophysics 485, 306320, doi:10.1016/j.tecto.2010.01.012 (2010). 
Acknowledgements: Lab assistance was provided by G. Eischeid, E. Northrop, E.

Kennedy, T. O'Brien, A. Breus, and A. Masterson. Thanks to G. Halverson, A. Bradley,

E. Tziperman, R. Summons, C. Hallmann, P. Huybers, and a suite of anonymous

reviewers for discussions and comments. We thank the Yukon Geological Survey, NSF

(EAR-IF 0949227: DTJ), KINSC (Haverford College), ESEP (Canadian Institute for

Advanced Research: PFH) and Harvard University for funding.

This project was conceived by DTJ, FAM and DPS. Field work was conducted by FAM, and PFH. Carbonate carbon analyses were performed by FAM. Organic carbon analyses and modeling were carried out by DTJ and BCG. The paper was written by all authors.

Figure 1: Chemostratigraphic sections through the Tayshir Member, Mongolia ${ }^{14}$. Red and gray represent carbonate carbon data from paired and unpaired samples, respectively (paired $n=235$ ). Two s.d. errors are smaller than the symbols. The stratigraphic key applies to both sections, and the stratigraphic section to the right was measured $35 \mathrm{~km}$ to the northeast; a distance shortened by the Cambrian Altaid orogeny

${ }^{14}$. Age constraints on the Dzabkhan volcanics are from ${ }^{32}$.

Figure 2: A chemostratigraphic section through the late Ediacaran of northwest Canada. As in Figure 1, red circles represent carbonate carbon and blue denotes paired organic carbon $(\mathrm{n}=73)$. Isotope scales are equal for carbonate and OC, and errors $(2$ s.d.) are smaller than the data points. Stratigraphic keys are the same as Fig. 1, as are the TOC (wt\%) calibrations. Abbreviations correspond to the following: $R a$, Rapitan; $T$, Twitya; and $I$, Icebrook. Carbonate data in the Keele and Twitya is from ${ }^{22}$ and overall trends are consistent with ${ }^{4}$.

Figure 3: A two-component mixing model built to address variability of $\delta^{13} \mathrm{C}$ with changes in TOC. Analytical precision for TOC measurements is $0.05 \mathrm{wt} \%$ (1 s.d.). (a) Where the mass fractions of each component are equal, traditional linear mixing is predicted. As one component increases in relative concentration, the mixing array becomes hyperbolic. The ratios listed on the figure denote the relative contribution of $A$ and $B$. (b) An example of the zone of possible solutions (red-hashed region) given contributions from a 1:10 mixing, as well as remineralization and post-deposition processes. These processes can alter samples to lower TOC, with modest changes in $\delta^{13} \mathrm{C}$. The data are binned by age: (c) interglacial records from Mongolia and northwest Canada, with additional data from the Ombaatjie Fm. (this study ${ }^{13}, \mathrm{n}=79$ ) and Trezona Fm. ${ }^{23}$, and (d) published Shuram data from Oman and China ${ }^{10,11}$. Note that the vertical axis is different in $\mathbf{d}$, however this model approach cleanly explains the excursion. 
Methods:

All isotope data are presented relative to Vienna PeeDee Belemnite (VPDB) and calculated according to standard delta notation and reported in units of \%. Carbonate carbon and oxygen isotope measurements made as one individual measurement, with the organic carbon isotopic composition measured separately, but on the same hand sample. Carbonate carbon isotopes were prepared by cutting hand samples to expose a fresh surface followed by micro-drilling $10^{-2}$ grams. A small aliquot of this powder was analyzed on a VG Optima run in dual inlet mode, abutted to a common acid bath preparation device. Samples were acidified in $\mathrm{H}_{3} \mathrm{PO}_{4}$ at $90^{\circ} \mathrm{C}$. The evolved $\mathrm{CO}_{2}$ was cyro-focused and analyzed against an in-house standard reference gas. The reproducibility of this measurement was better than $0.1 \%$ ( 1 standard deviation). Organic carbon analyses were performed on large $(\sim 10$ gram $)$ samples as to accommodate low TOC values. Samples were decalcified with concentrated $\mathrm{HCl}$ for 48 hours, buffered back to a neutral $\mathrm{pH}(>\mathrm{pH} 5)$, filtered, and dried. The mass of insoluble residue was taken as siliciclastic content. Homogenized residues were analyzed on a Carlo Erba Elemental Analyzer attached to a ThermoFinnigan Delta V configured in continuous flow mode. Samples and standards were bracketed such that our $>350$ unique organic carbon analyses (each run in duplicate) were associated with 370 internal standards. These standards have known organic carbon contents and isotope values, and as such, were used to calibrate TOC contents and isotopic compositions. Estimates of error are reported in the text.

The model presented in the manuscript is a multi-component mixing scenario, herein defined by a hyperbolic relationship. The equation represents a style of twocomponent

where: $\left(\delta^{13} C_{T O C}\right)_{M}=\left(\delta^{13} C_{T O C}\right)_{A} \times f_{A} \times\left(\frac{X_{A}}{X_{M}}\right)+\left(\delta^{13} C_{T O C}\right)_{B} \times\left(1-f_{A}\right)\left(\frac{X_{B}}{X_{M}}\right), \quad$ with the subscripts $M, A$ and $B$ representing the mixture, end-member $A$ and end-member $B$. There are two weighting factors $\left[f_{\mathrm{A}}\right.$, and $\left.\left(1-f_{\mathrm{A}}\right)\right]$, which are fractional terms seen in the equation describing linear mixing: $X_{M}=X_{A} \times f_{A}+X_{B} \times\left(1-f_{A}\right)$, where $X$ is mass. In solving this, we can choose the end member compositions $\left[X_{\mathrm{A}},\left(\delta^{13} \mathrm{C}_{\mathrm{TOC}}\right)_{\mathrm{A}}, X_{\mathrm{B}}\right.$, $\left.\left(\delta^{13} \mathrm{C}_{\mathrm{TOC}}\right)_{\mathrm{B}}\right]$ and allow $f_{\mathrm{A}}$ to vary from $0 \rightarrow 1$ (this is a relative flux term). This allows us to solve for $X_{\mathrm{M}}$ (from eqn. 2) and then $\left(\delta^{13} \mathrm{C}_{\mathrm{TOC}}\right)_{\mathrm{M}}$ from equation 1. For application in Figure 3, we can include the $\delta^{13} \mathrm{C}_{\text {carb }}$ on the same sample. 